\title{
TEACHING ENGLISH FOR SPECIFIC PURPOSES TO THE STUDENTS IN ENGLISH LANGUAGE TEACHING
}

\author{
Tira Nur Fitria \\ STIE AAS Surakarta \\ tiranurfitria@gmail.com
}

\begin{abstract}
This article provide 1) general overview and course design of English for Specific Purposes in the field of ELT (English Language Teaching), 2) the role of teachers and students in English for Specific Purposes (ESP), and 3) the difficulties related to teacher, student, environment and others in teaching ESP. In ELT, ESP concerns the specific English language needs of the target learners/students. It refers to teaching a specific genre of English for students with specific goals which is oriented and focused on English teaching and learning. ESP is designed and developed based on an assessment of purposes and needs and the activities for which English is needed. Some teacher's roles, such as asking to organize courses, setting the learning objectives, establishing a positive learning environment and evaluating the students' progress. While, the learners are related to a specific interest in learning, subject matter knowledge, and well-built learning strategies. In the implementation of ELT, there are difficulties/problems related to the teacher in teaching ESP, such as the low quality of lectures and textbooks, teachers' improper qualification and teaching methods and lack of a theoretical framework of teaching ESP. Difficulties related to the students, such as demographic characteristics and demands of learning ESP, English proficiency, differences between different languages, lack of vocabulary, depending on the dictionary and lack of skills in using dictionary especially ESP terms. While, the difficulties related to the environment and others are lack of teaching materials, classes with a too large student number, and heavily focused on the examination.
\end{abstract}

Keywords: English Language Teaching, English for Specific Purposes

\section{INTRODUCTION}

The term "specific" in English for Specific Purposes (ESP) refers to the specific purpose of learning English (Hans and Hans, 2015). The English for Specific Purposes (ESP) approach improves the relevance of what the students/learners are learning, then enables them to use English that they have known before. English for Specific Purposes (ESP) assesses the students/learners' needs and it integrates motivation, subject matter, and content for the teaching of relevant skills.

Almost every subject has its own "term" used in the course, such as business, medicine, and various scientific and technical fields. These terms can be both much more complicated and complex. Because English is widespread, it is becoming more and more important to learn English for Specific Purposes (ESP). The most important learner's purpose for learning English is to communicate a set 
of professional skills and to perform specific job-related functions. English for Specific Purposes (ESP), therefore, built on an assessment of purposes and needs and the functions for which English is required.

English for specific purposes (ESP) refers to the teaching and learning of English as a second or foreign language where the goal of the learners is to use English in a particular domain (Fitria, 2019). Hans and Hans (2015) state that English for Specific Purposes (ESP) more concentrates on language in context than on teaching grammar and language structures. It covers subjects varying from accounting or computer science to tourism and business management etc. An important point in ESP that English is not taught as a subject separated from the students' real world, but it is integrated into a subject matter area important to the learners. English for Specific Purposes (ESP), there is a needs analysis that determines which language skills are most needed by the students/learners, and the syllabus is designed appropriately for the students/learners. English for Specific Purposes (ESP) program can be used to emphasize the development of English skills in students/learners who are preparing for graduate work in business administration, or it promotes the development of spoken skills in students who are studying English in order to become tourist guides, etc. Based on the explanation above, it is perceived that ESP is goal-oriented and focused on English teaching and learning, designed for the specific learners according to learners' academic and needs.

The fact is English for Specific Purposes (ESP) combines subject matter and English language teaching like a combination is highly motivating because the students/learners can apply what they have learned in their English classes to their field of studies such as in accounting, business, management, economics, computer science, politic or tourism. Being able to use the vocabularies and structures that they have to learn in a meaningful context, it reinforces what is taught and increases their motivation in learning English. The students' abilities in their subject-matter fields, improve their skill to acquire or master English. Subject-matter knowledge gives the students/learners the context they need to understand English in the classroom. In English for Specific Purposes (ESP) classes, the students/learners are shown how the subject-matter content is expressed well in English. The teachers can make the most of the students' knowledge of the subject matter so that it helps them can learn English faster.

Therefore, in this article will provide: 1) general overview and course design of English for Specific Purposes in the field of ELT (English Language Teaching), 2) the role of teacher and student in English for Specific Purposes (ESP), and 3) the difficulties related to teacher, student, environment and others in teaching English for Specific Purposes (ESP).

\section{DISCUSSION}

\section{Nature of English for Specific Purposes (ESP)}

English for Specific Purposes (ESP) the emphasis is on "Specific English" that belongs to any particular discipline, occupation or activity (Javid, 2015). English for Specific Purposes (ESP) has become a fruitful field over the last three decades. (Ramirez, 2015). As a learner-centered approach, its main purpose has been that of fulfilling the specific needs of target learners to satisfy their professional or vocational demands. 
Hutchinson and Waters (1987) state that in English for Specific Purposes (ESP) context, the outcomes of the historical occurrences resulted from a number of people across the globe who wanted to learn the English language due to the key language in the fields of science, technology, and commerce. The emergence of English for Specific Purposes (ESP) teaching movement is caused by the English language needs of the learners for specific purposes in relation to their professions or job description. Howatt (1984) states that since the emergent years in the 1960s, ESP has become a vital and innovative activity within the Teaching of English as a Foreign or Second Language movement (TEFL/TESL).

Hutchinson and Waters (1987) define that ESP is an approach to language learning and it is based on learners' needs. It shows that ESP does not involve a particular kind of language, teaching material or methodology", but they suggest that the foundation of ESP involves the learners, the language required and the learning contexts which are based on the primacy of need in English for Specific Purposes (ESP).

Do and Cai (2010) state that ESP is English courses based on survey results and needs analysis in order to determine the specific activities that students/learners have to do as well as the final goal they want to achieve. Therefore, English for Specific Purposes (ESP) is an English course in which the textbooks and materials are adjusted to learners' desires and purposes. Robinson's (1991: 3) definition of ESP is based on two criteria they are: 1) ESP is normally 'goal-directed', and 2) ESP courses are developed from a needs analysis which aim to specify what exactly it is that the students have to go through the medium of English, and a number of characteristics which explain that ESP courses are generally constrained by a limited time period in which their objectives/goals have to be achieved and are taught to adults in homogenous and various classes in terms of the work or specialist studies that the students/learners are involved in.

Based on the definitions above, it can be concluded that English for Specific Purposes (ESP) is learning English for a specific purpose to get specific goals. Needs assessment or need analysis in ESP reaching ESP should not be considered as a different kind of teaching the language, but it is as an approach as it is also based on the common belief of teaching language for communicative purposes.

\section{Benefit of English for Specific Purposes (ESP)}

There are some benefits of English for Specific Purposes (ESP). The first, is learning speed. ESP results in the faster acquisition of required linguistic items. This is because it follows the pattern of native speaker acquisition of language for specific purposes, in which speakers learn what they need when they need it, inauthentic, content-based contexts. ESP is not only focused on these patterns but also improves upon it by providing an opportunity to learn in an accelerated, intensive context.

The second is learning efficiency. On an ESP, course trainees make the maximal use of their learning resources, all of which is brought to bear on acquiring specific, pre-identified linguistic items and skills. Obviously, the needs analysis is of vital importance, since it enables trainers to determine the specific requirements of teachers.

The third is learning effectiveness. On completion of an ESP course, teachers are ready to use language appropriately and correctly in job-related tasks, 
tasks that have been identified prior to the course by means of need analysis. Therefore, upon completion of the course, English is usable immediately in the employment context. In addition, teachers are prepared for further job-related training in English. Such preparations will give an impact on greater academic performance since no time is wasted in acquiring the necessary language.

\section{Characteristics of English for Specific Purposes (ESP)}

Dudley-Evans and John (1998) suggest that there are some characteristics of ESP, they are: (1) ESP meets specific purposes of the learners; (2) ESP uses the underlying methodology and activities of the discipline it serves; (3) ESP is centered and focused on the language appropriate to these activities in terms of grammar, lexis, register, study skills, discourse, and genre.

Besides that, ESP has some variable characteristics, such as (1) ESP is related to or designed for specific disciplines; (2) ESP may use in specific teaching situation, or even in different methodology from the general English; (3) ESP is likely to be designed or used for adult learners, either at a tertiary level institution or in a professional work situation. However, it can be taught to learners at the secondary school level. In some cases, ESP is also designed/focused for high school students; (4) ESP is generally designed for an intermediate or an advanced student, and (5) Most ESP courses assume that some basic knowledge of the language system, but it also can be used by beginners.

English for Specific Purposes (ESP) classes in a foreign language context can be differentiated from English for General Purposes which formerly is more directed towards the immediate professional or academic demands and applicable situations. It is not a straightforward task to give one overall definition for this area of teaching-learning to cover all of the courses offered today given the "growing body of research and theory, and ever-diversifying and expanding range of purposes" (Belcher, 2006: 134). This perception is complicated by the fact that there are differences between ESP in an EFL context compared to an ESL context.

\section{Course Design in English for Specific Purposes (ESP)}

Related to the fact that the students/learners have their objectives welldefined from the very beginning, these are directly related to their practical, jobrelated or professionally oriented needs, the choices the teachers have to make in designing a course.

ESP course basically should be based on three elements, they are: 1) ESP has to offer authentic materials, then it requires a purpose-related orientation, which means that a reasonable reality in which practitioners have the possibility to get involved in communicative tasks that replicate real situations is mandatory, and last but not least. 2) ESP should be defined by self -direction, i.e. learners are to become active users. 3) Then, in covering all areas of ESP that might play an essential role in the process of course elaboration, the ESP teachers should be ready to ask some questions and gather any information in the field to create an important database for further developments. The inquiries to be made are as following:

1. The reason students/learners need to learn.

2. Subjects/persons will take part in the process (teacher, student, an expert in the field). 
3. The place of the learning process going to take place. Whether the location provides any potential or imposes limitations.

4. Time of the learning process going to take place. It includes a time limit to be taken into consideration.

5. Things the student needs to learn. It relates to the aspects of the language that would be more appropriate under the given circumstances.

6. Goal the learning will be achieved. It relates to the theoretical background that will be chosen to fuel the methodology that is meant to be used.

In concerning the syllabus design, the teachers have to face the prospect of being bombarded with a great number of ready-made course books. However, it has been designed with the purpose of easing the teachers of their worries of searching for the authentic materials. They offer teachers the possibility to select activities that meet the needs of the learners, but at the same time force them into becoming "slaves" of the published textbooks, this plethora of resources, reducing "individual instructors" motivation to construct their own course content with a focus on the immediate learners "e context and particular needs".

The implication of the above-quoted points of view is that ESP practitioners/teachers should use textbooks as an alternative option, the suggested procedure/methodology being that of teachers collecting the empirical needsassessment data in creating and adapting materials to find the specific needs identified, these materials being selected, then able to "equip the students to deal with authentic examples of specialist discourse".

\section{Teacher Training in English for Specific Purposes (ESP)}

The teachers assume and believe that being a good communicator means that you must be a good teacher, but when they are put in the classroom environment, they find themselves looking for additional preparation to succeed in their teaching career. Richards and Farrell (2005) see that training courses are sets of activities designed not only for the general English teacher but also for the ESP one. Besides that, before dealing with the concept of the ESP teachers ${ }^{\text {ee }}$ training. It would like to clarify the difference between teacher training and teacher development. Teacher training means prepare the professional tasks for people who intend to teach English for the first time, which is also called a preservice training.

While teacher development refers to those activities which are oriented to experienced teachers. This is called in-service training (Larsen-Freeman 2001). Underhill (1986) states that In-service training is the process of increasing the teachers' knowledge to be "better" as a professional teacher, and it is in the form of activities for practicing teachers (Underhill 1986 is cited by Koyalan (2011). Such formal training courses are not always available. Most ESP teachers, for instance, seek their own way to develop themselves by saying, reading books, attending courses or workshops (Hutchinson and Waters 1987). Vassilakis (2011) maintains that the main goal that lies behind training teachers is to prepare them to develop some pedagogical roles such as in analyzing language and language skills in order to understand the learners' needs, providing the relevant materials and planning courses that match to those needs. 


\section{The Role of Teacher in English for Specific Purposes (ESP)}

Widdowson (1990) argues that the term "role" is used in various ways, but generally, a "role" is defined as a part of the performance in a certain social action. Wright (1987) states that in daily life, we have several social roles. In language teaching, a role determines the status of both the teacher and the student/learner, and it is subject to change, depending on the kind of activities happening in the classroom. For example, a teacher can be as an evaluator and a teacher at the same time (Nunan and Lamb, 1996).

Sierocka (2008) defines that the ESP teacher has more roles to play besides the role of a "teacher". Dudley-Evans and St John (1998) proposed five roles for the teacher, such as a course designer and material provider, researcher, collaborator, and evaluator.

\section{As a Teacher}

It is right that the ESP teacher is teaching the English language. However, the difference lies in the objective behind teaching (Harmer, 2001). In ESP a teacher does not mean only being a language provider, but also as a need analyst. Since the teacher is not the primary knower of the career content of the discipline, he/she has to understand his/her learners' needs to understand their knowledge of the content. Therefore, it can bring the relevant materials required by the group of learners in class (Bojovic, 2006).

\section{As a Course Designer and Materials Provider}

ESP course is to motivate the learners to use English both in an academic and a professional setting. Therefore, both ESP courses and materials are based on analyzing the learners' needs (Basturkmen, 2006). Course designers also should realize some basic questions before designing any courses. The teachers also can modify the activities to suit the learners' needs, and in case both possibilities are not in hand, the ESP teachers can generate their own (Dudley-Evans \& St John, 1998).

Hutchinson and Waters (1987) suggest some tips related to "materials providing". It is not always right that materials and courses are designed according to the learners' needs. However, teachers and sponsors' needs are also to be taken account of because if the teacher, for example, is not satisfied with the materials he/she provides this would affect the learners by losing and decreasing their motivation (Tomlinson, 1998).

\section{As a Researcher}

ESP plays an important position in English language teaching all over the world. It shows its way from language theories and research (Hyland 2009). Hence, the process of teaching ESP is restricted or limited to the findings in linguistic research in the target subject-specialty (Basturkmen 2006). According to Sierocka (2008), the ESP teachers have to research their own goal "in what they want to achieve" (Sierocka 2008: 35). Then, before designing courses or providing materials, the teachers need to do the researches in investigating the genres of texts, language, and skills required by the specific field of study (Dudley-Evans and St John, 1998). For example, ESP teachers often attend the 
classes, talks to the administration staff and investigates the strategies learners need in their learning (John and Price-Machado 2001).

\section{As a Collaborator}

The activities such as coordinating with colleagues are considered to be an essential step in any educational task (Nunan \& Lamb, 1996). ESP teacher does not have an exception since one of his/her roles is to cooperate with the subject specialist. The objective behind this cooperation is to know about the subject skills, tasks, and syllabus, also discover how the subject integrates with the language to bring the suitable material and courses for the learners (Dudley-Evans \& St John, 1998).

\section{As an Evaluator}

Evaluation is no exception to being an unconscious activity in our daily life. In language teaching, evaluation plays a role as feedback for learners and the course achievement. (Dudley-Evans \& St John, 1998). Evaluation should be carried out by the teachers because the teacher knows the learners' specialty and needs. Furthermore, he/she is expected to understand the classroom problems and knows the kind of evaluation which is relevant to his/her learners.

The teacher is usually involved in different types of evaluation. Bojovic (2006) states that in the context of ESP, there are two types of evaluation. First, the students' evaluation in which the teacher assesses whether the learners have the necessary language and skills to survive in the academic course or career, and in which he/she assesses the level of their achievement. Second, evaluation of the course and the teaching materials to measure the extent to which these suit the learners' needs.

\section{The Role of Students/Learner in English for Specific Purposes (ESP)}

English for Specific Purpose (ESP) refers to the teaching and learning of English as a second or foreign language where the purpose of the learners is to use English in a specific domain (Paltridge \& Starfield, 2014: 2). The students/learners are in ESP class with a specific interest in learning, subject matter knowledge, and well-built adult learning strategies. Students are in charge of developing English language skills to reflect their native-language knowledge and skills. They also have opportunities to understand with a language in a context that they comprehend and know

In this context, ESP has a powerful means for such opportunities. The students will acquire English as they work with materials which they find interesting and relevant that they can use in their professional work or even further studies. Students/learners in the ESP classes are generally aware of the purposes they will need to use English. Knowledge of the subject area enables the students/learners to identify a real context for the vocabulary and structures of the ESP classroom. They are constantly expanding vocabularies, becoming more fluent in their fields, and adjusting their linguistic behavior to new situations or new roles. ESP students can exploit these innate competencies in learning English.

\section{Difficulties Related to Teachers in English for Specific Purposes (ESP)}


There are some difficulties related to the teachers in teaching English for Specific Purposes (ESP) as following:

\section{Quality of Lectures and Textbooks}

In ESP courses, most materials are designed to develop skills in listening, speaking, reading, writing and translation, but some teachers believe that a good vocabulary is enough for the students/learners. Therefore, several textbooks developed by teachers do not bring the students much interest, because they usually focus only on reading skills and vocabulary exercises. According to Lam (2011), students/learners often forget the learned words after each exam.

\section{Qualification and Teaching Methods of Teachers}

The difficulties related to teachers they are teachers' qualification difference, teaching method difference, especially lack specialized knowledge because they are not allowed to take part in certain courses on methods and knowledge of teaching ESP. According to Ho (2011), the teachers also face problems related to course design, tasks, assignments and teaching methods. In the classroom, the students have to participate in group activities, presentations, taking minutes, writing English about the learned knowledge/topics. However, due to lack of time or lessons are sometimes not highly effective. Besides that, learning efficiency assessment is not accurate because the majority of exams are designed by the teachers.

\section{Lack of Theoretical Framework to Support Teaching English for Specific Purposes}

Chen (2011) defines that the theoretical framework in supporting teaching English for Specific Purposes (ESP) is the challenge. The biggest problem is there is no theoretical framework to support teaching ESP. There are many opinions on whether this subject should be considered as a compulsory subject in the curriculum or should be considered as a skill or practical knowledge to help the students/learners more confident with their knowledge after their graduation.

Difficulties Related to Students in English for Specific Purposes (ESP)

There are some difficulties related to the students in teaching English for Specific Purposes (ESP), as follows:

\section{Demographic characteristics and demands of learning ESP of the Students}

According to Suzini et al. (2011), the students' demand for ESP is not met adequately because of some reasons as follows: (1) students are not ready for ESP courses; (2) ESP classes are often too large/big; (3) sometimes ESP classes are delayed or canceled for some obvious reasons; (4) in some universities/high schools, the learners' motivation decreases because ESP courses are usually taken place in the summer; (5) students realize that ESP is too different from general English; (6) ESP teaching methods are still passive; (7) ESP teachers' qualification is inadequate. Besides that, most students have still used the traditional teaching and learning method. These results make the students passive when they take ESP courses, even they do not find ESP important for their future job/career. 


\section{English Proficiency}

The differences in students' proficiency in the same university/high school and among different universities/high schools harm teaching ESP. For example, the students in foreign language universities or foreign language departments of universities have higher proficiency in comparison with technical departments, social departments or other universities. Besides that, the residential area also has a significant impact on students' English proficiency. This makes the difficulty in using common ESP textbooks, especially for the students of departments which is not related much to English.

\section{Lack of Vocabulary}

Maruyama (1996) states that among students majoring in electrical engineering in Japan, he gave a list of 60 technical words to 112 students to identify the words and their meanings. However, there were 20 words none of the students knew, some words were known by a few students and only 1 word whose meaning all of 112 students understood.

Since then, Maruyama (1996) pointed out the reasons for students' lack of vocabulary: (1) The students believed that they did not need to know words because they were not common, even rarely used in their daily lives; (2) Therefore, they did not have motivation to learn the words, and (3) Most English teachers could not teach them these words because the teachers were not well acquainted with these scientific terms. Maruyama's assessment has many similarities to the actual situation. Many students also think that ESP terms are rarely used, especially in their daily lives, then they do not have the motivation to learn and remember them.

\section{Dependence on the dictionary and lack of skills in using a dictionary}

Lacking vocabulary especially of ESP terms, makes the students depend on the dictionary and get stuck whenever they encounter a new word (Maruyama, 1996). Specifically, when they see entirely new words, they cannot guess its meaning and they ignore it to understand the text. It is because the students do not have any knowledge of English etymology so that they cannot understand the meaning of a sentence when they do not know the meaning of a word or a few words in it. As a result, this dependence limits the flexibility and imagination of the learners. Lack of skills in using a dictionary is also a worrying problem. When using a dictionary, many students only pay attention to the first meaning of a word, they even do not concern with its other meanings and usages.

\section{Reading, listening, speaking and writing skills}

Concerning reading skills, Rezaei et al (2012) show that most learners/students had difficulties in identifying and understanding syntaxes of sentences. This makes reading English more difficult and sometimes the learners understand incorrectly sentence meaning. It is caused by too few scientific and technology English articles in universities, so the students are unfamiliar with ESP documents.

While, concerning listening and speaking skills, the students practiced these two ones very little in class because they spend most of their time learning grammar, vocabulary and reading text documents. Teachers do not pay attention 
to listening and speaking skill activities. They often give students two-language lectures (native language and English). Therefore, the students only remember individual words and cannot express their opinions in English for specific purposes.

\section{Difficulties Related to Environment and Others in Teaching ESP for the Students}

There are difficulties related to the environment and others in teaching ESP, as follows:

\section{Lack of Teaching Materials}

In many ESP training institutions, a technical facility for teaching ESP is mainly CD player; meanwhile, PowerPoint and electronic lessons are rarely used. Besides that, the ESP document is often developed by the teachers with no specialized knowledge, then the quality of those materials is low. Maruyama (1996) assumes that the ESP materials which show too high level which compared to the students' proficiency made students feel bored to learn. Besides, the students cannot expand their understanding because of limited knowledge of the textbooks. Many students admit and realize that they learn ESP because they have to learn but they want to and no longer remember learned knowledge after the examination. Classes with too Large Student Number.

According to Maruyama (1996), most students must take at least two years to learn English in universities, so that the student number of a class is up to 7090. It shows a significant impact on ESP teaching efficiency, especially when there is a difference in the students' proficiency. Most students find it is too difficult or too easy compared to their knowledge. Therefore, students do not have the motivation to study this subject.

\section{Heavily Focused Examination}

A heavily focused examination is also a big challenge for teaching ESP in universities, especially in Northeast Asian countries (Japan, Korea, China, Vietnam, etc). For example, in Japan. It is believed that the admission in a prestigious school from kindergarten to university is a prerequisite to ensure a good future for their children (Maruyama, 1996). This results in highly competitive exams. However, the effectiveness of these exams is not high because after these exams, the students usually quickly forget the learned knowledge.

\section{CONCLUSION}

English for Specific Purposes (ESP) is learning English for a specific purpose to get special or specific goals. Needs assessment or need analysis in ESP should not be considered as a different kind of teaching the language but rather as an approach as it is also based on the common belief of teaching language for communicative purposes. ESP is focusing on the specific needs of the learners, concentrating more on language in context. In the field of ELT (English Language Teaching), ESP is concerned with the specific English language needs of the target learners/students. It refers to teaching a specific genre of English for students with specific goals. The goal of ESP is oriented and focused on English teaching and learning, designed for the specific learners according to learners' 
academic and professional needs. ESP course is developed based on an assessment of purposes and needs and the activities for which English is needed. However, in ESP it is a needs analysis that determines which language skills are most needed by the learners, and the syllabus is designed accordingly.

In the implementation of ELT, there are some difficulties related to the teacher in teaching English for Specific Purposes (ESP) as follows: quality of lectures and textbooks, qualification and teaching methods of teachers and lack of a theoretical framework to support teaching ESP. Difficulties related to the students such as demographic characteristics and demands of learning ESP of students, English proficiency, differences between language to another, especially ESP, lack of vocabulary, dependence on the dictionary and lack of skills in using dictionary especially ESP terms. While, the difficulties related to the environment and others are lack of teaching materials, classes with a too large student number, and heavily focused examination.

\section{REFERENCES}

Basturkmen, H. (2006). Ideas and Options in English for Specific Purposes. New Jersey: Lawrence Erlbaum Associates Inc.

Belcher, Diane D. (2006). English for specific purposes: Teaching to perceived needs and imagined futures in worlds of work, study and everyday life. TESOL Quarterly 40(1), 133-156. Cambridge, Cambridge University Press. http://dx.doi.org/10.1017/cbo9780511733031

Chen, Y. (2011). The institutional turn and the crisis of ESP pedagogy in Taiwan. Taiwan International ESP Journal, 3(1), 17-30.

Dickins, R. R \& Germaine, K. (1992). Evaluation. UK: Oxford University Press.

Đỗ, T. X. D., \& Cai, N. D. A. (2010). Teaching and learning English in new context: Challenges and Solutions. Journal of Science, Hue University, 26 $(60$

Dudley-Evans, T \& ST John, M. (1998) Developments in English for Specific Purposes: A Multi-Disciplinary Approach. UK: Cambridge University Press.

Fitria, T. N. (2019). BUSINESS ENGLISH AS A PART OF TEACHING ENGLISH FOR SPECIFIC PURPOSES (ESP) TO ECONOMIC STUDENTS. Jurnal Education and Economics, 2, 10.

Hans, A., \& Hans, E. (2015). A Comparative Study of English for Specific Purposes (ESP) and English as a Second Language (ESL) Programs. International Journal on Studies in English Language and Literature (IJSELL), 3(11), 26-31.

Ho, B. (2011). Solving the problems of designing and teaching a packed English for specific purposes course. New Horizon in Education, 59(1), 119-136.

Howatt A. P. R. (1984). A History of English Language Teaching. Oxford: Oxford University Press

Hutchinson, T., \& Waters, A. (1987). English for Specific Purposes: A Learning Centered Approach. Cambridge: Cambridge University Press 
Javid, Choudary. Z. (2013). English for Specific Purposes : Its Definition, Characteristics, Scope and Purpose. European Journal of Scientific Research, 112(1), 138-151.

John, A. M \& Price-Machado, D. (2001). English for Specific Purposes: Tailoring Courses to Student Needs-and to the Outside World in Celce-Murcia, M (Ed) Teaching English as a Second or Foreign Language. USA: Heincle and Heincle Inc.

Koyalan, A. (2009). The Evaluation of a Self-Access Centre: A useful addition to class-based teaching? System, 37, 731-740.

Larsen-Freeman, D. (2001) "Second Language Teacher Education" in Carter, R \& Nunan, D (ed) The Cambridge Guide to Teaching English to Speakers of Other Languages. UK: Cambridge University Press.

Maruyama, H. (1996). Difficulties in Teaching Technical English in Japan. Revista de Lenguas para Fines Específicos, 3.

Nunan, D. \& Lamb, C. (1996). The Self-Directed Teacher: Managing the Learning Process. UK: Cambridge University Press.

Paltridge, B., \& Starfield, S. (2014). The Handbook of English for Specific Purposes. John Wiley \& Sons.

Ramirez, C. G. (2015). English for Specific Purposes: Brief History and Definitions. Revista de Lenguas Modernas, 23, 379-386.

Rezai, A., Rahimi, M. A., \& Talepasan, S. (2012). Exploring EFL Learners Reading Comprehension Problems in Reading ESP Texts. Sino-US English Teaching, 9(3), 982-987.

Richards, J. C \& Schmidt, R. (2002) Longman Dictionary for Language Teaching and Applied Linguistics. Malaysia: Pearson Edition.

Robinson, P. (1991) ESP Today: A Practitioner's Guide. Hemel Hempstead: Prentice Hall International.

Sierocka, H. (2008). The role of the ESP teacher, in www. teacher.pl. 2, 56: 3337. Retrieved in April 10, 2019.

Suzani, S. M., Yarmohammadi, L., \& Yamini, M. (2011). A critical review of the current situation of teaching ESP in the Iranian higher education institutions. The Iranian EFL Journal, 7(6), 179-204.

Vassilakis, G. (2011). Teacher Development? What do you mean?. Marisa Constantinides. South African Journal of Education. (4), 12 -17.

Widdowson, H. G. (1990). Aspects of Language Teaching. China: Oxford University Press

Wright, T. (1987). Roles of Teachers and Learners. Hong Kong: Oxford University Press. 